認めなかったと報告された。しかし，これはペースメー 力患者で心拍数が 70 と一定にしてあり，心拍数を変化さ せた場合も適用できるか検討していただきたい。

Factor analysisも新しい心機能解析法であり， 548， 549席伴に同じ処理プログラムである. Factor は 7 つ程 あり, 臨床の解析には $2 \sim 5$ factor で一つの機能評価を 行っている. 549席の大村氏は, できるだけ少ない factor で解析する方が後の分析がやりやすいこと． $2 \sim 3$ factor の組み合せが適当であると述べた.この特徵は, 従来 の phase image 法に比べて両心室の重なりや正常部と 異常部の重なりのある症例に有用であり, 自動短時間処 理のできる利点があるので適用範囲を広げる検討をお䫝 いしたい.550席の動態解析モデルは動態解析の精度と再 現性を確かめるのに非常に有用な模型と実験であると思 われるが，解析モデルが人体の機能にどれだけ近似して いるかが容易には吞み込めないきらいがあった。

全体として心機能評洒の最先端のことを行っているの だが, 実際に行っている人は理解していても途中の経過 説明が一般的に不足して, 理解し難いのではないか. 前 提条件と結果が強調されすぎていると思われた。

\section{RI-17 検査薬剤一1}

座長 立花敬三 （兵庫医科大学病院 RI センター診療部）

\section{I-123-IMP を用いた SPECT イメージングに関す る基礎的検討}

兵庫医科大学病院 RI センター診療部

前田善裕・立花敬三・西川彰治 尾上公一・木谷仁昭・浜田一男 成田裕亮

宝塚市立病院中央放射線部 獚野重喜

局所脳血流の評価法としてI-123-IMPを用いた SPECT に関心が向けられつつある.I-123 製郕には少量 の I-124 の混在が知られている。実際の蹊床応用に際し， I-124の影響を少なくし，良好なイメージを得るため, 感 度, 空間分解能, コントラスト分解能, 均一性等を指標 に最適コリメータの検討を行い, 併せて, 再構成時のフ イルタおよびサンプリングタイムにつき検討した、コリ メータは低エネルギー汎用型が適し，サンプリングタイ 厶は30秒以上で満足する情報量が得られた。また再構成 時のフィルタによる差は認められなかった。臨床応用に 際しては，イメージエディ夕を用い om-lineでの transaxial slice を作成した。
554.スラントホールコリメータを用いた ${ }^{123}$ I-IMP の 脳血流イメージング

\author{
大阪市立大学病院中放部 \\ ○下西祥裕・池田穂積 \\ 浜田国雄・大村昌弘 \\ 大阪市立大学医学部 越智宏暢
}

〔目的〕 ${ }^{123}$ I-IMP を用いた脳血流 SPECTに30傾斜 のスラントホールコリメータ使用の有用性を中エネルギ ーパラレルホールコリメータの場合と比較し検討した。

〔結果〕スラントホールコリメータの方が感度にやや すぐれ, 分解能, スライス厚, 久損検出能の面において あきらかにすぐれていた。均一性はほぼ同じであった。

スラントホールコリメータを SPECT に用いることに より，その画質を改善することができた。

555. ${ }^{123} I-I M P$ による SPECT 脳シンチグラフィの基礎 的, 臨床的検討

国立循環器病センター

○林 眞・横山博典・小倉裕樹

与小田一郎・松井泰伸

(目的〕 ヨードアンフェタミン ( ${ }^{123}$ I-IMP) は脂肪親和 性があり, 脳に多量取り込まれることから脳シンチグラ フィに適するといわれているので，その撮像に適するコ リメータの選択とその特性を調べた。また，臨床的には 脳血流を反映した最適撮像時間の検討と撮像時期におけ る脳血流分布の経時的変化を調べた。

〔結果〕Planar 像では中エネルギー汎用型が散乱力 ブリも少なく鮮明であるが SPECT 像では低エネルギー 高分解能コリメー夕の方が感度が高く得られ, 分解能の よい画像が得られた。静注 30 分後が IMP の集積が脳で プラトーに達し，初期血流分布を反映した。静注 2 時間 以後で初期分布と異なる様相を呈するがこれは脳組織の viability，PH-シフト，拡散，血流因子などが考えられ る.

556. N-Isopropyl- ${ }^{123} I$-p-Iodoamphetamine (IMP) に よる脳血流イメージングの基礎的検討

名古屋大学医学部附属病院放射線部

○安部哲太郎・西野正成・亀山裕司 野口英三・松浦 浩

IMP による脳血流イメージングにおいて良い画質を 得るために，(1)コリメータの選択(核的純度による影響) (2)至適撮像開始時間および経時的体内分布 (3)デー夕収 集, 処理条件について検討した、コリメ一夕の選択はそ の性能，収集時の条件等によって左右され施設ごとに検 討が必要と思われる。当院では phantom 実験により, 